\title{
Modern hydro-biological state of the Small Aral sea
}

\author{
N. Aladin ${ }^{1}$, J.-F. Crétaux ${ }^{2, *, \dagger}$, I. S. Plotnikov ${ }^{1}$, A. V. Kouraev ${ }^{1,3}$, A. O. Smurov ${ }^{1}$, \\ A. Cazenave ${ }^{1}$, A. N. Egorov ${ }^{1}$ and F. Papa ${ }^{1,4}$ \\ ${ }^{1}$ Zoological Institute, Russian Academy of Sciences, Lab of Brackish water biology, St Petersburg, Russia \\ ${ }^{2}$ Laboratoire d'Etudes en Géophysique et Océanographie Spatiales (LEGOS), Toulouse, France \\ ${ }^{3}$ State Oceanography Institute, St. Petersburg branch 199026, St. Petersburg, Russia \\ ${ }^{4}$ Observatoire de Paris, Lerma 61 av de l'observatoire, 75014 Paris
}

\begin{abstract}
SUMMARY
Due to water withdrawal for land irrigation purposes, the Aral sea was definitively separated into two lakes, the Small and Large Aral, in the late 1980s. Since then, both lakes have followed their own hydrobiological evolution. The Large Aral is continuously drying out at a rate of around $80 \mathrm{~cm} / y e a r$, and is now at a level $10 \mathrm{~m}$ below the Small Aral, in the north. We discuss the evolution of the Small Aral during the 1990s in terms of hydrological water mass balance and consequences on hydrobiology. A satellite altimetry technique has been used to monitor the variation of the Small Aral sea level every ten days from 1993 up to 2003. During the same period various in-situ data have been collected: salinity of the sea, runoff of the Syr Darya, evaporation and precipitation over the lake, and biological parameters related to phytoplankton, zooplankton and zoobenthos. During this period a dam in the Berg's strait has been built and the flow of the Syr Darya has been artificially channelled in order to retain the water from the Syr Darya river inside the Small Aral sea. This dam was not sufficiently resistant to water pressure and was destroyed many times. However, it led to a significant increase of the level of the Small Aral, and a decrease in salinity, and thus has had a significant effect on biomass and bio-productivity, and hence on fishery activities. The short period when the dam was installed has demonstrated the positive influence on future possible restoration and rehabilitation of the marine ecosystem in the Small Aral. Copyright (C) 2005 John Wiley \& Sons, Ltd.
\end{abstract}

KEY WORDS: Aral Sea; water balance; hydrobiology; radar altimetry

\section{INTRODUCTION}

The Aral Sea (Figure 1), which was one of the world's largest inland water-bodies, with a surface of $66000 \mathrm{~km}^{2}$ and a volume of more than $1000 \mathrm{~km}^{3}$, started to shrink at the beginning of the $1960 \mathrm{~s}$, when anthropogenic demands for agricultural use led authorities to increase the irrigation intake of the two inflow water contributors: the Amu Darya and Syr Darya rivers (Micklin, 1988). Aral Sea level variation measurements have been made from the beginning of the 20th century, and these data show that fluctuations did not exceed a few meters (Micklin, 1988; Glantz, 1999). In 1960 the level of the sea was $53 \mathrm{~m}$ above the Baltic Sea level (taken as usual with reference to zero sea level). Amu Darya and

*Correspondence to: J.-F. Crétaux, Laboratoire d'Etudes en Géophysique et Océanographie Spatiales (LEGOS), Toulouse, France ${ }^{\dagger}$ E-mail: Jean-Francois.cretaux@ notos.cst.cnes.fr 
Syr Darya provided around $60 \mathrm{~km}^{3}$ of fresh water runoff per year, which represents approximately half of the total runoff capacity flow of both rivers. The other half was lost by evaporation, underground infiltration loss and irrigation along the $3000 \mathrm{~km}$ river length. When withdrawal of water for irrigation increased in 1960, the equilibrium of the water was broken, and the level declined very rapidly and reached $39 \mathrm{~m}$ in 1989 at the time of separation of the Aral sea into the two lakes: Small (northern part) and Large (southern part) Aral seas (see Figure 1a). During this period from 1960 to 1989, the average salinity of the sea increased from $10 \mathrm{~g} / \mathrm{l}$ to $28 \mathrm{~g} / \mathrm{l}$. These abrupt changes of water level and salinity due to intensive irrigation were accompanied by several consequences: degradation of deltaic ecosystems (reduction in vegetation and wildlife), salinization of the soil and chemical pollution of the rivers,

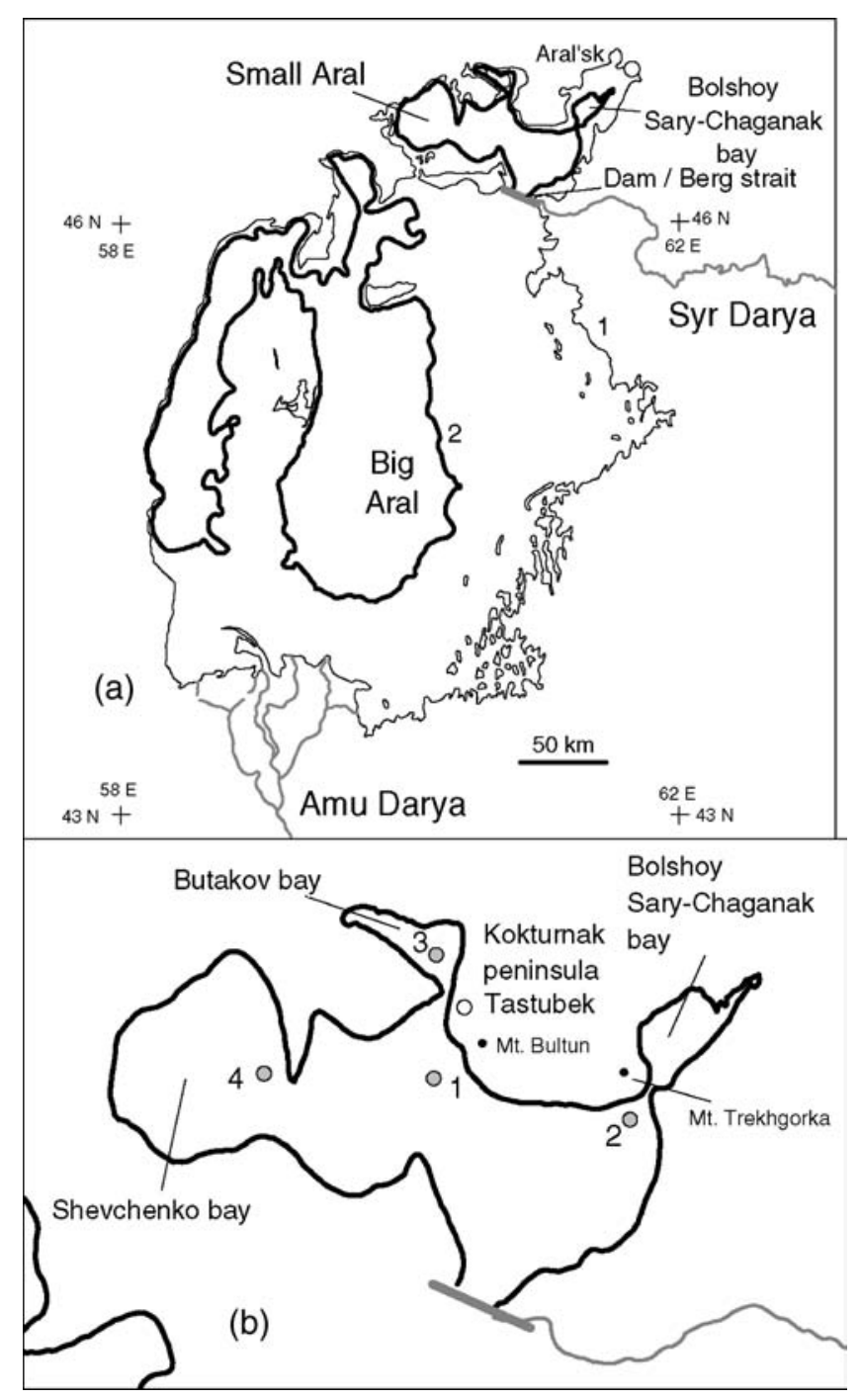

Figure 1. (a) The Large and Small Aral seas. Location of the Aral sea coastline in 1966 (1) and 2002 (2). (b) Map of the Small Aral sea with location of the points of primary production measurements 
climate changes (dust storms, changes in precipitation regime and temperature, regional warming, decline of fish population, increases in human diseases (high morbidity rate, typhoid, cancer, congenital deformities, etc.), economic disaster for fishermen of the Aral sea (fishery stopped in 1979 in the north and 1984 in the south). All of the above is widely documented in numerous articles (Micklin, 1988; Aladin et al., 1995; Bortnik, 1999; Glantz, 1999; Letolle and Chesterikoff, 1999; Small et al., 2001, etc. ...).

Prior to anthropogenic desiccation, the average salinity in the Large and Small seas differed to some extent. The differences were insignificant during the period from 1961 to 1970 because of water exchange between the two basins. Historically, Amu Darya downstream runoff $\left(45 \mathrm{~km}^{3} /\right.$ year before 1960) was more than as great as runoff from Syr Daria (18 km³/year) (Zholdasova, 1999). In late 1970s to mid-1980s almost no water from Syr Darya river reached the Aral sea, while Amu Daria still supplied some water (less than $10 \mathrm{~km}^{3} /$ year) to the Aral sea. During this period, from 1971 to 1985 , after the Auzykokaral strait dried up, and Berg's strait became shallower, the average salinity in the Small Aral became 1.5-3.0 g/l higher than in the Large Aral. However, in 1986 the difference in average salinity between the Small and Large seas decreased again, primarily because of a change in the direction of flow of the Syr Darya, which resulted in the diversion of more freshwater into the Small sea. Since 1988, the average salinity in the Small Aral has decreased by $1.5-2 \mathrm{~g} / \mathrm{l}$ when compared with the Large Aral. Subsequently, the complete drying of Berg's strait in spring 1990 has been followed by still sharper differences in salinity concentration between the two basins.

In 1989, the fauna and flora of the Small and Large Aral were rather similar, but since then biological differences between these two water bodies appeared very quickly, principally due to different hydrological regimes. In 1961, the whole Aral sea was a brackish lake with an ecosystem characterized by low biodiversity and biological productivity except near the delta, where relatively high productivity remained. When salinization increased, the ecosystem moved to mesohaline, with predominance of marine species of fishes and invertebrates.

The presence of species is indeed strongly associated and dependent on the rate of salinity in the sea: when it grew to above $14 \mathrm{~g} / \mathrm{l}$ in the mid-1970s, brackish water species of fresh water origin partly disappeared: only $30 \%$ among the 160 species of benthic inhabitants survived. After the 1980 s, when salinity grew to more than $20 \mathrm{~g} / \mathrm{l}$, many other brackish water species were lost and only euryhaline invertebrates still survived. The diversity of phytoplankton also decreased during this period (Aladin, 1999).

Evolution of both lakes followed radically different evolutions during the 1990s: the Large Aral continued to rapidly dry up because of the high rate of evaporation not compensated by river inflow, precipitation and ground waters. In the beginning of the 1990s, Amu Darya still supplied around $15 \mathrm{~km}^{3}$ of water per year in the Large Aral sea and delta (Zholdasova, 1999) due to several years of precipitation in the Pamir mountains. In the mid-1990s water runoff decreased again, and the level of the Large Aral in 2002 was 10 m lower than in the Small Aral. Since separation of the two lakes, the Small Aral receives run-off from the Syr Darya, and because of the smaller surface of this lake, the evaporation is quite balanced by ground waters, precipitation and river runoff. These differences in the hydrological regimes of the two lakes has thus led to the stabilization of the Small Aral sea level and continued desiccation and salinization of the Large Aral. The ecological situation is also different between the two lakes, primarily due to the difference in salinity. In the Large Aral, salinity actually reached more than $75 \mathrm{~g} / \mathrm{l}$ in the western part, and more than $150 \mathrm{~g} / \mathrm{l}$ in the eastern part (Mirabdullayev et al., 2003). This difference comes from the morphology of both basins, deep and small in the west, shallow and large in the east, both parts being separated now. In the Small Aral, salinity reach only $20 \mathrm{~g} / \mathrm{l}$. We will not discuss in this article the question of the restoration of the Large Aral, which is quite improbable in the near future. The Large Aral will certainly continue to desiccate because 
rehabilitation would require too much water from Amu Darya, which is actually used for irrigation. Its ecosystem will turn into the ecosystem typical of hyperhaline water bodies in arid zones with probable evolution of salinity up to $200-300 \mathrm{~g} / \mathrm{l}$ and even more, where only bacteria will survive.

For the Small Aral the question of restoration is still opened, especially now, as a Russian company (Zarubezhvodstroy) started in summer 2003 to build a new dam, which is due for completion in 2005. During the last decade, a dam was built in the Berg's strait, which allowed the water level to rise and salinity to decrease. The Dam was destroyed and rebuilt many times, and the aim of our study is to establish evidence of the possibility of restoration and rehabilitation of the ecosystem in the Small Aral. Rising water and decreasing salinity result in increasing biodiversity due to both natural causes and reintroduction of fishes and invertebrates from regions near the Syr Darya delta. We first of all try to assess the water balance during the last decade thanks to satellite remote sensing and in-situ data.

TOPEX/Poseidon and Jason-1 satellite data that are available over the Small and Big Aral seas were used to compute both lake level variations from 1993 to 2003 . Here we present only results on the Small Aral sea. To use lake level time series as a proxy data for water mass balance budget, it is required to transform it in terms of variations of volume. A bathymetry map of the Small Aral has been used for this purpose. A 10 day resolution time series of Small Aral volume variations over the last 10 years has been computed and confirmed the positive effect of a dam in the Berg's strait. As we show later, during the periods of the dam, $80 \%$ of Syr Darya river supplies water to Small Aral, and thus the level increased and salinity decreased, while in the periods when there was no dam, only $20 \%$ of Syr Darya river ran to the Small Aral sea, which is not sufficient to overfill the lake, which would thus shrink again. Over the same period, benthos samples zooplankton and phytoplankton have been analysed, and according to results, the positive influence of construction of the dam in Berg's strait was verified.

\section{DATA AND METHOD}

To stress the correlation of dam presence with variation of Small Aral we have used satellite altimetry data that allow us to accurately monitor inland water level variations with a time resolution of ten days. The TOPEX/Poseidon (T/P) and Jason platforms have two nadir-looking instruments - a dualfrequency radar altimeter and a passive microwave radiometer. The radar altimeter transmits a short pulse in the nadir direction, which is then reflected by the sea surface, and the measurement of the time for the pulse to be reflected back to the altimeter corresponds to the distance between satellite and sea surface. Several corrections must be applied to this measurement, due to atmospheric refraction, geoid height, tides and electromagnetic bias, and then substracting this altimetry measurement to the height of the satellite above the ellipsoid gives the sea surface height. The altimetry missions as T/P or Jason were designed to study the open ocean, but the potential of the radar altimetry technique over continental water, lakes or rivers has been rapidly recognized (Birkett, 1995; Cazenava et al., 1997). Many lakes are not surveyed by in-situ measurement, in particular when they are located in remote areas. In addition, even when in-situ observations exist, they are often difficult to obtain. This is mainly the case of Aral Sea. A precise and complete description of application of satellite altimetry to lakes or rivers can be found in Birkett $(1995,1998)$.

\section{SMALL ARAL WATER LEVEL AND SALINITY}

We discuss in this section the modern evolution of Small Aral level and salinity: 1993 to 2003. From 1989, at the time when the Aral sea was divided into two lakes, the level of the Small Aral was $39 \mathrm{~m}$. It 
first started to rise due to positive water balance (Aladin, 1995). As a result of rise in water level during spring 1990, a small but strong out-flowing channel appeared in the area of Berg's strait, and it once again allowed water flow from the Small to the Large Sea. In spring 1992, the flow rate from the Small to the Large Aral averaged $100 \mathrm{~m}^{3} / \mathrm{s}$. From this period up to 1997, six periods can be considered for studying the variation of lake level and water balance: three periods with the presence of the dam in the Berg's strait and three periods without any dam.

In July 1992 this channel was filled up with sand to build a $1 \mathrm{~m}$ high dam in order to control the water level in the Small sea, and to rehabilitate this basin (Aladin et al., 1995; Aladin, 1995). The first attempt to construct a dam failed as the water pressure was too great, and the dam collapsed.

A second dam was constructed in late July/early August which stayed in place for 9 months. The dam was destroyed when the water pressure and wave action became too critical. This corresponds to the first period, after which the local authorities regularly rebuilt the dam many times, making it stronger each time.

Then from spring 1993 to spring 1996, corresponding to period 2 without a dam, a new dam was in place from April 1996 to May 1997 (period 3), followed by another period without a dam (period 4 from May 1997 to October 1997), then a large period with a solid dam (period 5 from October 1997 to April 1999), and the last period considered is the period from April 1999 until May-June 2003 without a dam in Berg's strait.

For these six periods we have computed the variations of the Small Aral level deduced from altimetry measurements of T/P and Jason-1 satellites. Then using a bathymetry digital map of the Small Aral sea, these fluctuations have been converted into time series of volume variation that can be related to other hydrological parameters through the classical water mass balance equation:

$$
\mathrm{d} V / \mathrm{d} t=(R+P)-(D+E)+\left(G_{\mathrm{i}}-G_{\mathrm{o}}\right)
$$

Thus fluctuations in lake volume may reflect changes in precipitation $(P)$ and evaporation $(E)$ integrated over the lakes and their catchment basins, river discharge $(R)$ and outflow $(D)$, and ground water inflow and outflow $\left(G_{\mathrm{i}}\right.$ and $\left.G_{\mathrm{o}}\right)$, which is usually unknown.

Since there is no river outflow in the case of the Small Aral sea $(\mathrm{D}=0)$, and since $G_{\mathrm{i}}, G_{\mathrm{o}}$ are supposed to be negligible (Small et al., 1999), (1) became:

$$
\mathrm{d} V / \mathrm{d} t=R+P-E
$$

If evaporation and precipitation are given as cm/year, (2) can be re-written as

$$
\mathrm{d} V / \mathrm{d} t=R+S(t)(P-E)
$$

where $S(t)$ is the surface of the lake at the time of measurement.

To determine $\mathrm{d} V / \mathrm{d} t$ we have created a digital bathymetry model based on a map of the bottom surface topography of the Small Aral.

In (3), we thus used the left member as a known parameter, and in the right member, we used for precipitation and evaporation initial values obtained in Small et al., 1999, and listed in Table 1. For the runoff of the Syr Darya $(R)$ we used an initial value obtained on an Internet web site (http:// water.freenet.uz) thanks to research made in the frame of an INTAS program (Ivan Stavitsky, personal communication). Monthly runoff are measured in Kazalinsk, around $100 \mathrm{~km}$ before the mouth of the delta. Data are given as monthly values from 1913 to 1996. For 1997 to 1999 we used annual averaged 
Table 1. Precipitation and evaporation over the Aral sea basin expressed in centimeter/month, deduced from figures given in Small et al., 1999

\begin{tabular}{lcccccccccccc}
\hline & Jan & Feb & Mar & Apr & May & Jun & Jul & Aug & Sep & Oct & Nov & Dec \\
\hline$P(\mathrm{~cm})$ & 2.5 & 2 & 2.5 & 2.3 & 2 & 1.3 & 1 & 0.8 & 0.8 & 1.7 & 2 & 2.5 \\
$E(\mathrm{~cm})$ & 8 & 4 & 3 & 3 & 10 & 11 & 16 & 20 & 15 & 10 & 10 & 9
\end{tabular}

runoff measurements in Kazalinsk provided by the Institute of Hydrology of Almaty (Dusen Sadykov, personal communication).

Then we estimated, through an inverse least square adjustment, based on 11 years of continuous series of $\mathrm{d} V / \mathrm{d} t$ on a 10-day time resolution, 3 unknown parameters of (3) re-written as follows:

$$
\mathrm{d} V / \mathrm{d} t=\alpha_{\mathrm{d}} R_{\mathrm{d}}+\alpha_{\mathrm{nd}} R_{\mathrm{nd}}+\beta S(t)(P-E)
$$

where $\alpha_{\mathrm{d}}$, and $\alpha_{\text {nd }}$ are factor coefficients of runoff for dam periods and no dam periods. It thus represents the attenuation factor of estimated effective water inflow into the Small Aral sea with respect to water runoff measured in Kazalinsk. In other words it also represents the effect of the dam, which may induce a different rate of water loss before reaching the Small Aral in the two possible configurations, where $R_{d}$ and $R_{n d}$ characterize the Syr Darya runoff in Kazalinsk in the case of dam and no dam, respectively.

The $\beta$ coefficient (estimated for the whole period) allows us to quantify more precisely the precipitation minus evaporation rate and is estimated in the inverse processing.

We have ascertained that during dam periods (period 1, 3 and 5) $80 \%$ of river runoff measured in Kazalinsk reaches the Small Aral, while only 20 to $25 \%$ reaches when no dam is present in the Berg's straits. In this case part of the water is lost in the delta, as in the case of 'dam period', but also some non-negligible amount of water is lost in the desert between the Small and Big Aral and does not return to the Small Aral.

For the $\beta$ coefficient we have estimated a value of 1.1. It shows that, with respect to evaporation and precipitation rates deduced from the Global Climatological model based on data prior to the 1990s (Small et al., 1999), the current evaporation is around 10\% higher now. It is in good agreement with analysis of the effect of desiccation of the Aral sea on the regional climate, which indicates that the annual rate of precipitation minus evaporation should become more negative in the water budget (Small et al., 2001). It is associated with increasing temperature in spring and summer, and decrease in winter (Small et al., 2001).

These results can be illustrated in Figures 2 and 3. They represent the time series of level and volume fluctuations, respectively.

It shows first of all annual fluctuations mainly due to evolution in evaporation, which is high in summer and around zero in winter. The presence of ice and snow in winter on the Aral sea may also affect the altimetry measurement and induce higher errors in water level due to the penetration effect of the radiation ice-covered surface (Birkett et al., 1995; Kouraev et al., 2003). Secondly, a significant interannual signal is observed in the sea level and volume times series which coincides with the periods with and without the dam. In late 1992 to the end of 1993 then late 1996/early 1997 and finally from October 1996 to April 1999, the increase in the level and volume is significant and coherent with the estimation of $\alpha_{\mathrm{d}}$, and during the three periods without the dam, the decrease of the lake level and volume is dominant and coherent with the value of $\alpha_{\text {nd }}$ estimated using (4) applied on all data available 


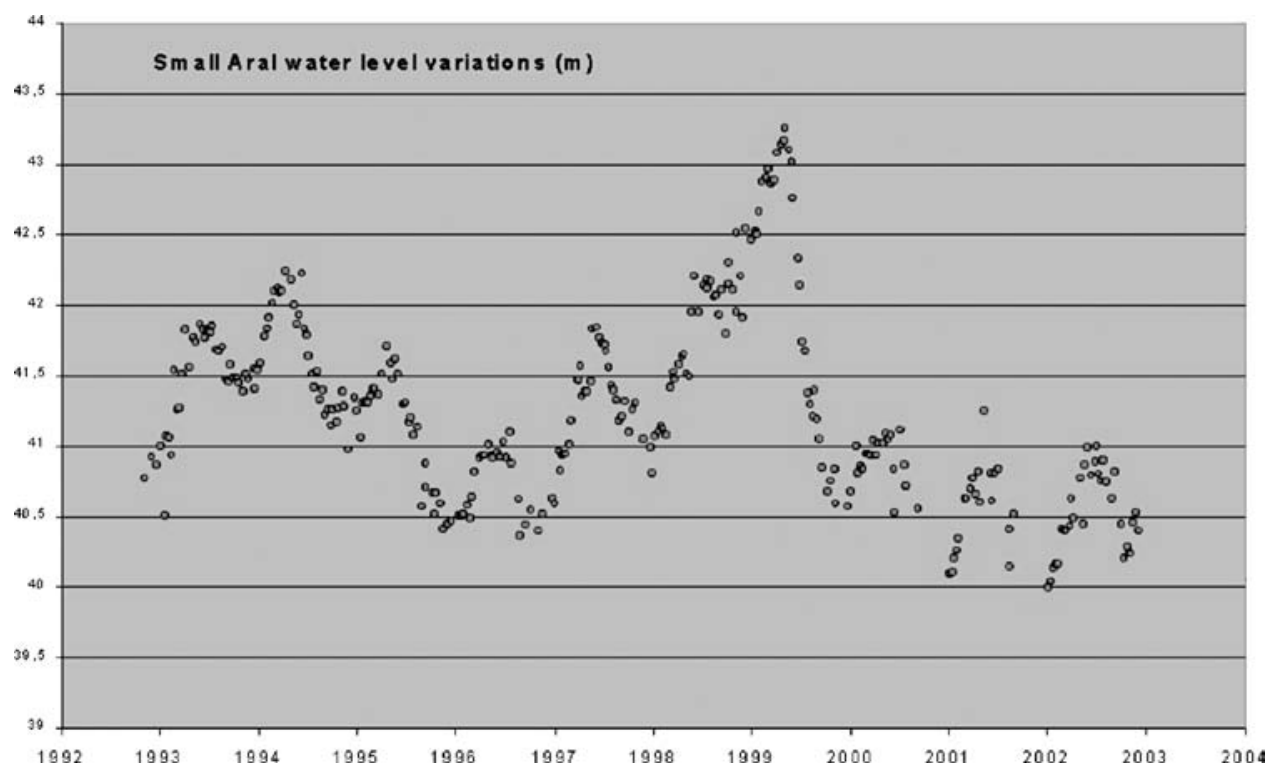

Figure 2. Small Aral level variation deduced from satellite altimetry

during no dam periods. Since April 1999, when the last dam was destroyed, the level of the Small Aral has continued to decrease.

This is just another proof (by satellite data) of the positive effect of a dam on the Small Aral sea.

Figure 4, which represents variations of salinity of the Small Aral since 1989, confirms this tendency. From 1992 to 1993 the salinity decreased from $27-28 \mathrm{~g} / \mathrm{l}$ to $20 \mathrm{~g} / \mathrm{l}$, then increased again up to

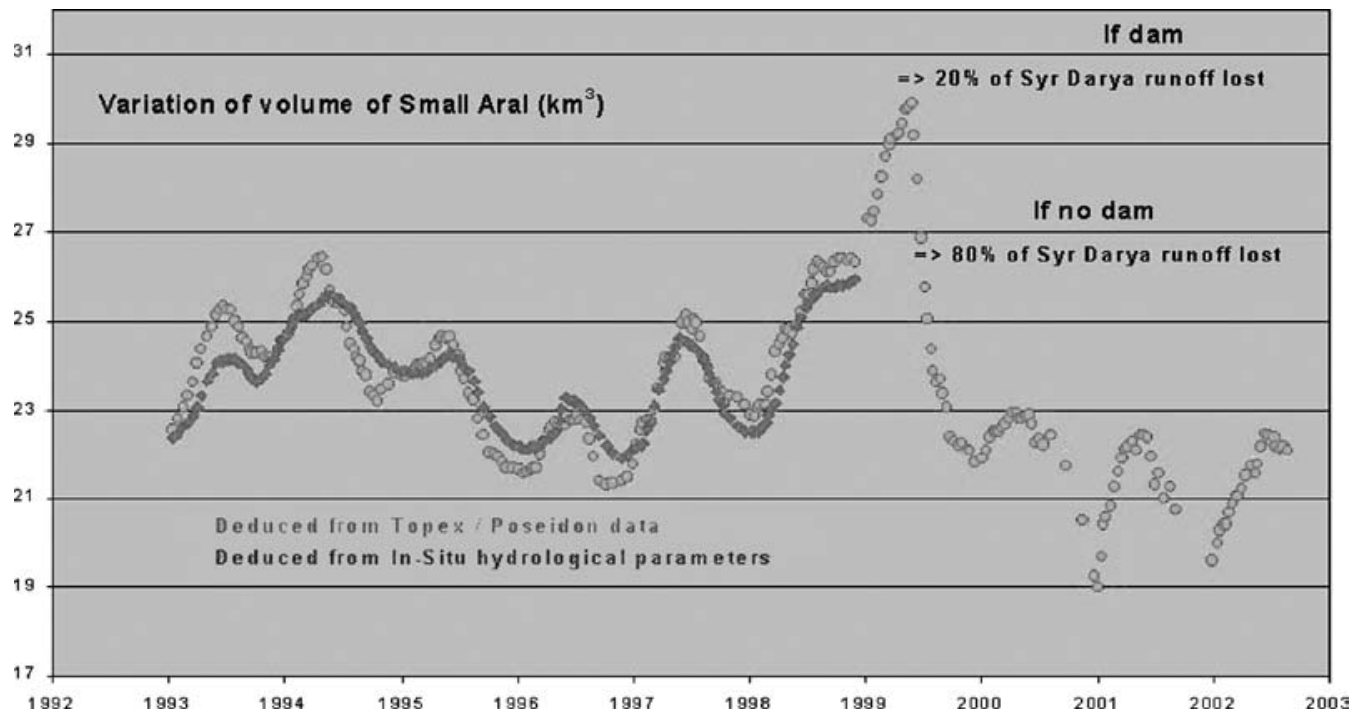

Figure 3. Variation of volume of Small Aral deduced from satellite altimetry and from hydrological in-situ measurements. Amount of runoff data from Syr Darya river to Small Aral has been adjusted considering initial values measured in Kazalinsks 


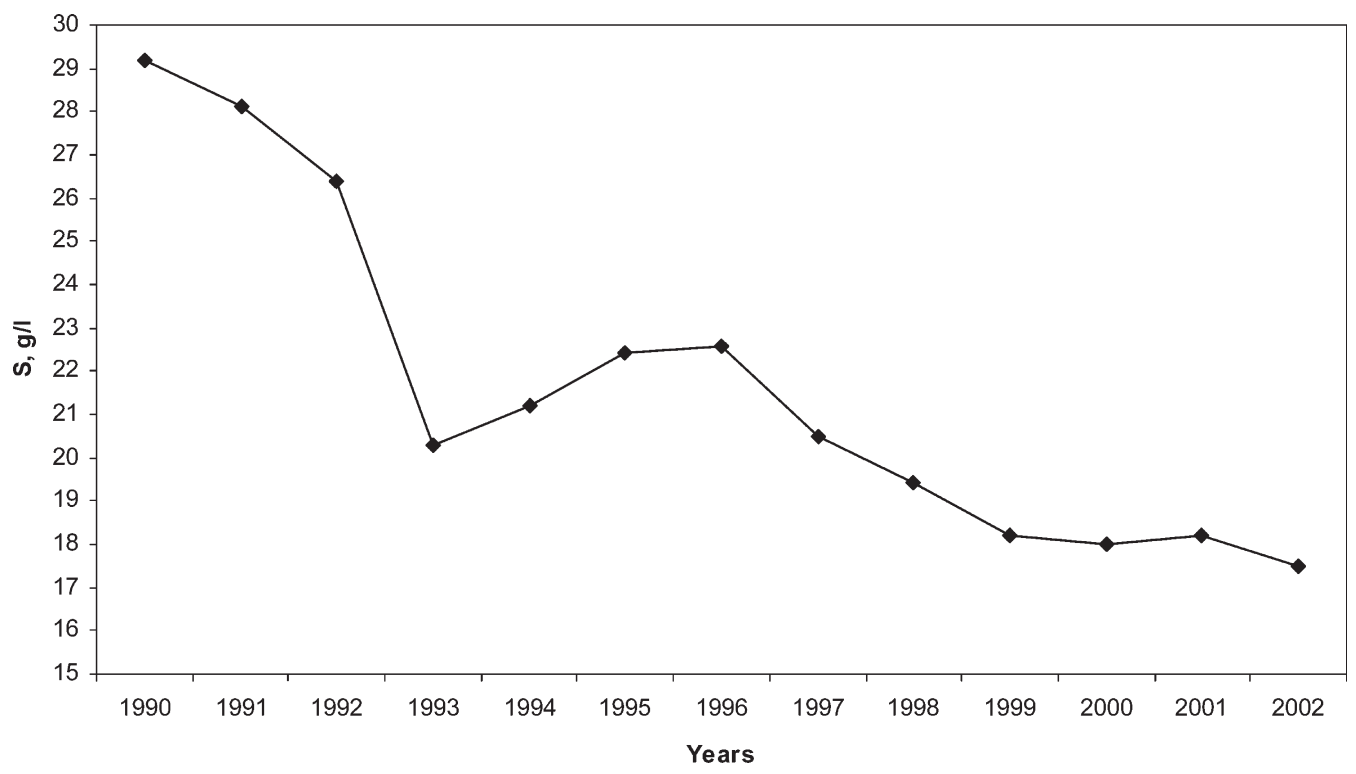

Figure 4. Average salinity changes in the Small (northern) Aral sea

1996, reaching around 22-23 g/l, and then decreased again to $18 \mathrm{~g} / \mathrm{l}$ during the long dam period 5 , after which it stopped decreasing.

It was quite predictable that the dam in the Berg's strait should contribute filling the Small Aral. We have estimated through hydrological in-situ, and remote sensing satellite data, the impact of the dam on the variation of the volume of the lake. It is thus possible to foresee evolution of this water body in the following years as a dam is now under construction. To do this, we have first estimated that the runoff water in Kazalinks during the period from May 1999 to the end of 2002 was around 9 to $10 \mathrm{~km}^{3}$ / year. This value has been obtained by inversion of the water mass balance equation based on variation of volume during this period and assuming that only $20 \%$ of water passing through Kazalinsk gauge supplies the Small Aral.

Now let us suppose first of all that there is a dam in the Berg's strait and that runoff water remains at $10 \mathrm{~km}^{3} /$ year in the next years. Figure 5 shows that this will lead to a rapid fill in of the Small Aral basin. The sea will reach in less than 20 years the level it had before desiccation, which was around $53 \mathrm{~m}$ above the Baltic Sea. Under this hypothesis, the amount of runoff of Syr Darya will be too high and should be diminished. Figure 5 shows that an annual runoff of $7 \mathrm{~km}^{3}$ in Kazalinsk is the upper limit which will allow it to reach the former level of the Small Aral, considering that $80 \%$ of this water runoff will supply the sea. In that case the volume of the Small Aral will be $72 \mathrm{~km}^{3}$ and the surface $5650 \mathrm{~km}^{2}$.

If, now, we assume that construction of a dam has not been decided, let us see what should be the evolution of the Small Aral. This is given in Figure 6. In the case of an annual runoff of Syr Darya of $10 \mathrm{~km}^{3}$ as estimated in Kazalinsk for the last 3-4 years, the level of the Small Aral would continue to decline with a low rate of centimeters per year down to the value of 37 meters, a volume of $12 \mathrm{~km}^{3}$ and a surface of $2000 \mathrm{~km}^{2}$ in 40 years. Figure 6 also shows the variation in the level of the Small Aral for the next 80 years in the case of less runoff water of Syr Darya, which could lead to a very low level of around $30 \mathrm{~m}$ after 30 to 40 years, a volume of $2.2 \mathrm{~km}^{3}$ and a surface of $2000 \mathrm{~km}^{2}$. 


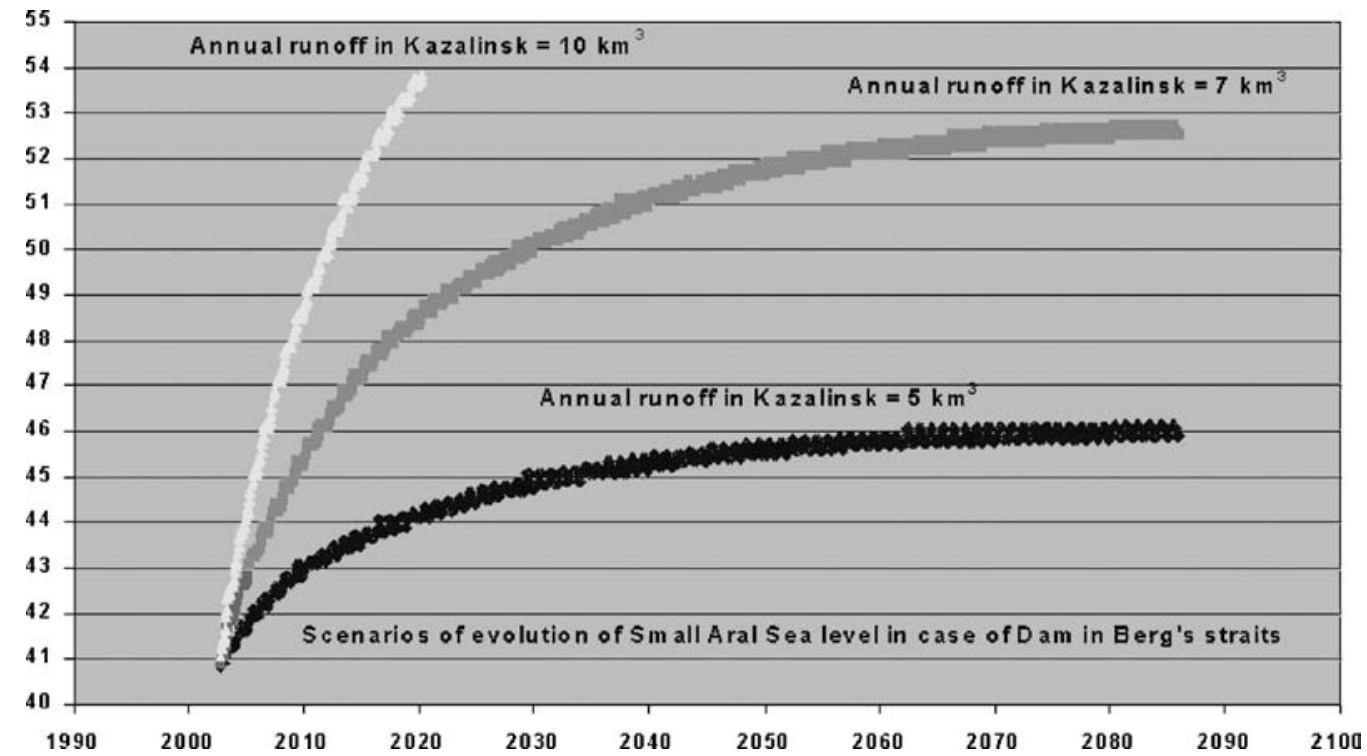

Figure 5. Evolution of Small Aral level (m) if a dam in the Berg's straits is built in various scenarios of water runoff of Syr Darya river. Historical level of $53 \mathrm{~m}$ can be reach in the next 80 years with a runoff of only $7 \mathrm{~km}^{3}$ in Kazalinsks. In this case the Small Aral will be fully restored

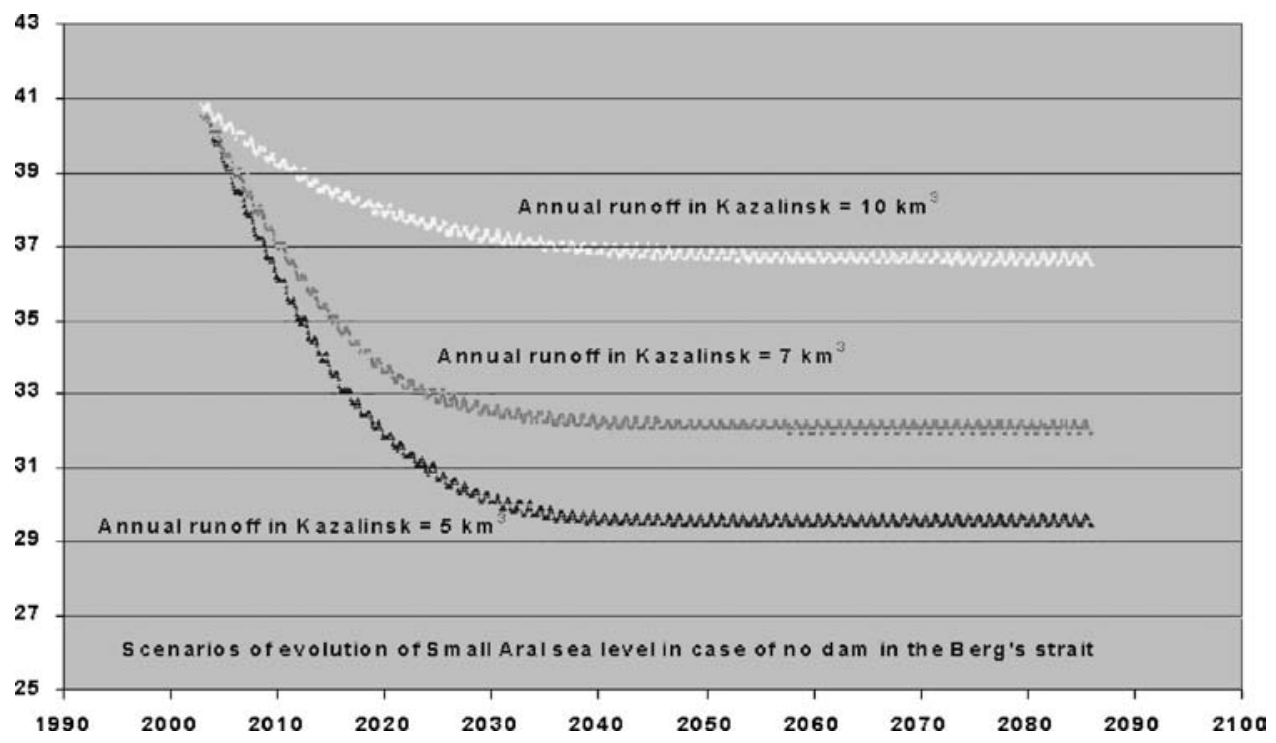

Figure 6. Evolution of Small Aral level $(\mathrm{m})$ in the case of no dam in the Berg's straits in various scenarios. Depending on the runoff of Syr Darya, the Small Aral would dropped to a level ranging from 4 to $8 \mathrm{~m}$ below the actual level 
These simple simulations of possible scenarios of evolution of the Small Aral stress the need to both build a solid dam in the Berg's strait (the level should increase by $12 \mathrm{~m}$ above the actual level) but also to control the runoff of Syr Darya, or to elaborate a system of dikes with flow control gates (this solution has been adopted for the dam system actually under construction). This could allow restoration of the morphometric characteristics of the Small Aral (level, surface and volume), for which an initial condition to decrease the salinity and rehabilitate the marine ecosystem, as we see in the next sections.

The second objective of this analysis was to investigate the impact of a dam on the biological ecosystem. Few measurements have been conducted during the 1990s concentrating on phytoplankton, zooplankton and zoobenthos analysis. We aimed to find some positive evidence of the influence of the dam during this decade on these parameters.

\section{PHYTOPLANKTON PRIMARY PRODUCTION ANALYSIS}

Phytoplankton primary production was measured during our field studies at the Small Aral sea in 1999. This allows us to compare recent data with those obtained in our earlier expeditions (Dobrynin and Koroleva, 1991; Orlova, 1993, 1995; Orlova and Rusakova, 1995). Water samples were taken on four stations (Figure 1b, Table 2). They were exposed at station 1 located about $2 \mathrm{~km}$ from the expedition camp in the open sea opposite Tastubek cape. On station 1 water samples were taken from three horizons and were exposed of them. At the other stations only integral water samples were taken because of their remoteness from the camp. They were exposed over one day at a depth of $0.5 \mathrm{~m}$. During sampling, hydrological and weather conditions were identical (Table 2). Water transparency by Secchi disk was up to the bottom, the only exception being at station 2 near Trekhgorka, where a storm took place and water transparency did not exceed $0.5 \mathrm{~m}$ during water sampling. The oxygen content determination in water samples was carried out according to Winkler's method: water samples were exposed in two light and two dark bottles following titration with thiosulfate.

Table 2. Hydrological characteristics and daily values of phytoplankton primary production in the Small Aral sea in September 1999

\begin{tabular}{|c|c|c|c|c|c|c|c|c|c|c|}
\hline \multirow[t]{2}{*}{ Date } & \multirow[t]{2}{*}{ Station } & \multirow[t]{2}{*}{ Weather } & \multirow[t]{2}{*}{$H_{\mathrm{st}}, \mathrm{m}$} & \multirow[t]{2}{*}{$T_{\mathrm{s}}^{\circ} \mathrm{C}$} & \multirow[t]{2}{*}{$S, \mathrm{~m}$} & \multirow[t]{2}{*}{ Salinity, } & \multirow{2}{*}{$\begin{array}{l}\text { Horizon } \\
\mathrm{g} / 1\end{array}$} & \multirow[t]{2}{*}{$\mathrm{O}_{2}, \mathrm{mg} / \mathrm{l}$} & \multicolumn{2}{|c|}{ Assimilation (A) } \\
\hline & & & & & & & & & $\mathrm{mgC} / \mathrm{l}$ & $\mathrm{mgC} / \mathrm{m}^{3}$ \\
\hline \multirow[t]{3}{*}{ 16. IX } & $\begin{array}{c}1 \\
2 \mathrm{~km} \text { from }\end{array}$ & $\begin{array}{l}\text { weak } \\
\text { rough }\end{array}$ & 3.0 & 18.7 & $\begin{array}{l}\text { to the } \\
\text { bottom }\end{array}$ & $21-22$ & surface & 0.31 & 0.12 & 120 \\
\hline & the camp & & & & & & 1.5 & 0.31 & 0.12 & 120 \\
\hline & & & & & & & bottom & 0.30 & 0.11 & 110 \\
\hline 17. IX & $\begin{array}{c}3 \\
\text { Butakov } \\
\text { bay }\end{array}$ & $\begin{array}{l}\text { weak } \\
\text { rough }\end{array}$ & & 20.7 & $\begin{array}{l}\text { to the } \\
\text { bottom }\end{array}$ & $21-22$ & integral & 0.31 & 0.12 & 120 \\
\hline 20. IX & $\begin{array}{c}2 \\
\text { Near } \\
\text { Trekhgorka } \\
\text { mountain }\end{array}$ & storm & 2.0 & 18.2 & 0.5 & & integral & 0.65 & 0.24 & 240 \\
\hline 21. IX & $\begin{array}{c}4 \\
\text { Shevchenko } \\
\text { bay }\end{array}$ & $\begin{array}{l}\text { weak } \\
\text { rough }\end{array}$ & & & & & integral & 0.62 & 0.23 & 230 \\
\hline
\end{tabular}


Further determination of phytoplankton primary production was carried out according to Vinberg's method (Table 2). The photosynthetic process at the sampling points occurred in the whole water column from the surface to the bottom, reaching a maximum in the upper $1.5 \mathrm{~m}$ layer, insignificantly decreasing to the bottom. This agrees with data we obtained earlier (Dobrynin and Koroleva, 1991; Orlova, 1993, 1995; Orlova and Rusakova, 1995). For example, studies in 1993 (Orlova and Rusakova, 1995) have shown that maximum values of photosynthesis activity were at a depth of $2 \mathrm{~m}$, according to Dobrynin and Koroleva (1991), and maximum values of phytoplankton primary production were at a depth of $0.5 \mathrm{~m}$. Results of our recent studies as well as data of previous observations did not reveal distinct patterns in spatial distribution of phytoplankton primary production. The highest values of phytoplankton primary production were registered at station 2 near Trekhgorka and in Shevchenko bay (station 4), where they approached $0.25 \mathrm{mgC} / 1$ per day (Table 2). Overall, values of phytoplankton primary production obtained in 1999 were within the range of those obtained by other authors, while the mean levels of primary production was slightly lower than in previous years.

For the period of investigation, during which the dam has maintained the salinity of the Small Aral sea at a quite stable and small value, primary production of phytoplankton has changed very little.

\section{ZOOPLANKTON ANALYSIS}

In September 1997, zooplankton sampling was made only in Butakov bay, being an atypical part of the Aral. In September 1999, zooplankton samples were taken in the Small Aral at Tastubek peninsula and Bultun mountain, near Trekhgorka mountain, in central deepwater area, in Shevchenko Bay and in Butakov bay.

In zooplankton samples the following invertebrates dominated and were found: rotifers Synchaeta vorax and S. cecilia, copepods Calanipeda aquaedulcis and Halicyclops rotundipes aralensis, cladocerans Podonevadne camptonyx and Evadne anonyx (both absent in Butakov bay), larvae of bivalves Abra ovata and Cerastoderma isthmicum. Data on abundance and biomass of zooplankton are given in Tables 3 and 4.

Investigations has shown that, during years 1996-1999, some changes connected with changes in hydrological and hydrochemical regimes of the Small Aral occurred in zooplankton of this lake. Water salinity decrease in the Small Aral resulted in the growth of the cladocerans abundance (up to 5-10\% of the total zooplankton quantity) and biomass $\left(3218 \mathrm{ind} . / \mathrm{m}^{3}\right.$ and $16.1 \mathrm{mg} / \mathrm{m}^{3}$ ) in comparison with the

Table 3. The Small Aral sea zooplankton abundance (ind. $\left./ \mathrm{m}^{3}\right)$ and biomass $\left(\mathrm{mg} / \mathrm{m}^{3}\right)$ in September 1999 , ind. $/ \mathrm{m}^{3} \mathrm{mg} / \mathrm{m}^{3}$

\begin{tabular}{lccccc}
\hline Location & Rotatoria & Copepoda & Cladocera & Mollusca larvae & Total \\
\hline Near Tastubek & 1578 & 2497 & 415 & 1446 & 5934 \\
Near Trekhgorka mountain & 2.9 & 8.7 & 2.1 & 3.2 & 14.4 \\
& 22207 & 9494 & 3218 & 8529 & 43448 \\
Central water area & 40.0 & 23.5 & 16.1 & 18.8 & 98.3 \\
& 8910 & 666 & 1249 & 666 & 11492 \\
Shevchenko bay & 16.0 & 2.5 & 6.2 & 1.5 & 26.3 \\
\multirow{2}{*}{ Butakov bay } & 5640 & 3301 & 688 & 3026 & 12655 \\
& 10.2 & 5.5 & 0.4 & 6.7 & 25.8 \\
& 712 & 5220 & 0 & 1305 & 7237 \\
& 1.3 & 9.7 & 1.3 & 13.9 \\
\hline
\end{tabular}


Table 4. Abundance (ind. $\left./ \mathrm{m}^{3}\right)$ and biomass $\left(\mathrm{mg} / \mathrm{m}^{3}\right)$ of Butakov bay zooplankton in September 1997, ind. $/ \mathrm{m}^{3} \mathrm{mg} / \mathrm{m}^{3}$

\begin{tabular}{lrrrr}
\hline Station & Rotatoria & Copepoda & Mollusca larvae & Total \\
\hline 1 & 449.7 & 3597.5 & 0 & 4047.2 \\
& 0.8 & 8.7 & 0 & 9.5 \\
2 & 1557.7 & 1713.5 & 155.8 & 3427.0 \\
& 2.8 & 2.5 & 0.3 & 5.6 \\
3 & 259.5 & 9082.0 & 259.5 & 9600.9 \\
& 0.5 & 14.4 & 0.6 & 15.4 \\
4 & 334.5 & 3679.0 & 0 & 4013.5 \\
& 0.6 & 6.0 & 0 & 6.6 \\
6 & 10480.2 & 5240.1 & 0 & 15720.3 \\
& 18.9 & 7.7 & 0 & 26.6 \\
7 & 13570.1 & 29997.0 & 238.1 & 43805.1 \\
& 24.4 & 43.8 & 0.5 & 68.7 \\
11 & 3394.7 & 3637.2 & 363.7 & 7395.6 \\
& 6.1 & 5.2 & 0.8 & 12.1 \\
\hline
\end{tabular}

figures of the first half of the 1990s (375 ind. $/ \mathrm{m}^{3}$ and $1.9 \mathrm{ind} . / \mathrm{m}^{3}$, respectively), as was predicted (Plotnikov, 1993, 1995a, b). Now P. camptonyx is one of the main and persistent components in the zooplankton after copepod Calanipeda aquaedulcis, rotifers Synchaeta spp, and larvae of bivalve molluscs (the last are numerous only in summer). Nevertheless, Podonidae were not found in Butakov bay, where the salinity was higher than in the main water area of the Small Aral (Plotnikov, 1991, 1993, 1995b). It is noteworthy that Evadne anonyx has been again. After its disappearance in the 1980s, this cladoceran was absent in the Aral sea for a long time because of the high salinity.

In May 1996 we registered in the Small Aral sea zooplankton sharp and substantial growth of a number of rotifers from the genus Synchaeta $\left(12500-59000 \mathrm{ind} . / \mathrm{m}^{3}\right)$ in comparison with the first half of the 1990s (430 ind./m³ in 1993) (Plotnikov, 1993; 1995a, b). In September 1999 the abundance of rotifers remained high (1600-22000 ind. $/ \mathrm{m}^{3}$ ). In comparison with the water area near the Tastubek peninsula, a number of rotifers and their relative proportion in zooplankton were increased in the central part of the Small Aral sea, as was observed in 1996. Thus in the second half of the 1990s rotifers are dominating in zooplankton of the Small Aral. This could be connected with the increase of the intensity of the primary producing process in the Aral sea (Dobrynin, Koroleva, 1991; Orlova, 1995).

The abundance and biomass of bivalve mollusc larvae, one of the main components of the Aral sea zooplankton, were low (but still did not reach a minimum). It is normal for this season when their reproduction period is finished. Copepods were represented mainly by $\mathrm{C}$ aquaedulcis. As usually H. $r$. aralensis was not numerous (Plotnikov, 1995a, b).

There are differences between zooplankton in the examined areas of the Small Aral sea. Among them the water area in the north-east near Trekhgorka mountain stand out. Here zooplankton abundance and biomass are higher than in other localities at the Kokturnak peninsula (43500 ind./ $\mathrm{m}^{3}$ and $98 \mathrm{mg} . / \mathrm{m}^{3}$ as against $5900 \mathrm{ind} . / \mathrm{m}^{3}$ and $14.4 \mathrm{mg} / \mathrm{m}^{3}$ ). A similar difference was observed earlier, in 1993 (Plotnikov, 1995a, b). We could suppose that it is connected with proximity of this water area to the Syr Darya delta. Waters of the Syr Darya are bringing nutrients (biogenes and suspended organic matter), and supply of those leads to an increase in productivity of aquatic ecosystems. So, this water area is characterized by high values of primary production. In the past, as well as in the beginning of 
the 1990s, the highest abundance and biomass of zooplankton were observed in the water area adjoining the delta (Plotnikov, 1995a, b).

Butakov bay is to some extent isolated from the main water area of Small Aral, but unlike the Bolshoy Sarycheganak bay is not losing communication with it. This bay is characterized by the unstable state of zooplankton, which is expressed in significant fluctuations of its number and biomass. Most sharply they are expressed in C. aquaedulcis. Another feature of zooplankton in this bay is the constant presence of H. $r$. aralensis in it. This crustacean, in the time of the zooplankton depressive state, can even predominate over C. aquaedulcis (Andreev, 1991; Plotnikov, 1991, 1993, 1995b).

In 1997 (Table 4), rotifers Brachionus sp., Synchaeta vorax and S. cecilia, copepods Halicyclops rotundipes aralensis, Calanipeda aquaedulcis, larvae of bivalve molluses Abra ovata and Cerastoderma isthmicum were found in the zooplankton of Butakov bay. Copepods H. r. aralensis, not numerous in the open water areas of the Small Aral, Calanipeda aquaedulcis, and also rotifer Synchaeta spp., were prevailing as before. The larvae of bivalve molluscs - one of the dominants in spring-autumn zooplankton-were in very low numbers. In 1997 the abundance and biomass of autumn zooplankton in Butakov bay (3400-43 800 ind. $/ \mathrm{m}^{3}$ and $9.5-68.7 \mathrm{mg} / \mathrm{m}^{3}$ ) were much higher than in the autumn of 1990 and 1991 (Plotnikov, 1995a, b). Here, as well as in 1996 in the main water area of the Small Aral, the number of fine rotifers Synchaeta cecilia, not numerous before, had increased to a higher extent than the number of $S$. vorax. Except for water area adjoining the bay's mouth (station 6,7), where the abundance of rotifers had increased, composition, quantitative parameters of zooplankton development in different sites of Butakov bay were similar (Table 4). In 1999 (Table 3), zooplankton of Butakov bay had its typical structure, and parameters of its quantitative development were comparable with those observed in autumn 1997. It is worth noting that plankton larvae of bivalve molluscs were more numerous in comparison with the same season in 1997. It shows that variability of reproduction dynamics in these bivalves depends on inter-annual variability of environmental factors.

Damming the Berg's strait allowed some stability of the zooplankton community to be kept. As soon as salinity slightly and gradually decreased, the bio-diversity of zooplankton improved.

\section{ZOOBENTHOS ANALYSIS}

Zoobenthos studies were undertaken in September 1997 at the Butakov bay and in September 1999 in the central part of the Small Aral sea. In 1999 for the investigation of vertical zoobenthos distribution in the inshore zone of the Tastubek village, hydrological transect was made at the depth of $0.7,1.5,3$ and $6 \mathrm{~m}$ (Aladin et al., 2000).

In the Butakov bay, zoobenthos comprised all the benthic taxa characteristics for the modern Aral sea: bivalves Abra ovata (=Syndosmia segmentum) and Cerastoderma isthmicum gastropods Caspiohydrobia and polychaetes Nereis diversicolor. Average zoobenthos density and biomass were rather high and reached $646 \mathrm{~g} / \mathrm{m}^{2}$ and 42.3 th.ind. $/ \mathrm{m}^{2}$ (Table 5). Bivalve A. ovata dominated in terms of both density and biomass at all the stations. Other species distribution was homogeneous, the same set of species was recorded at each station and their relative biomass varied between stations insignificantly.

The character of vertical distribution of individual species of benthic invertebrates, macrophytes and coarse organic debris in sediments has its own peculiarities in this region and differs a great deal from that in the major part of the Aral sea. The abundance of both macrophytes and detritus as well as A. ovata and Caspiohydrobia spp. biomass were maximum in shallower waters and decreased with 


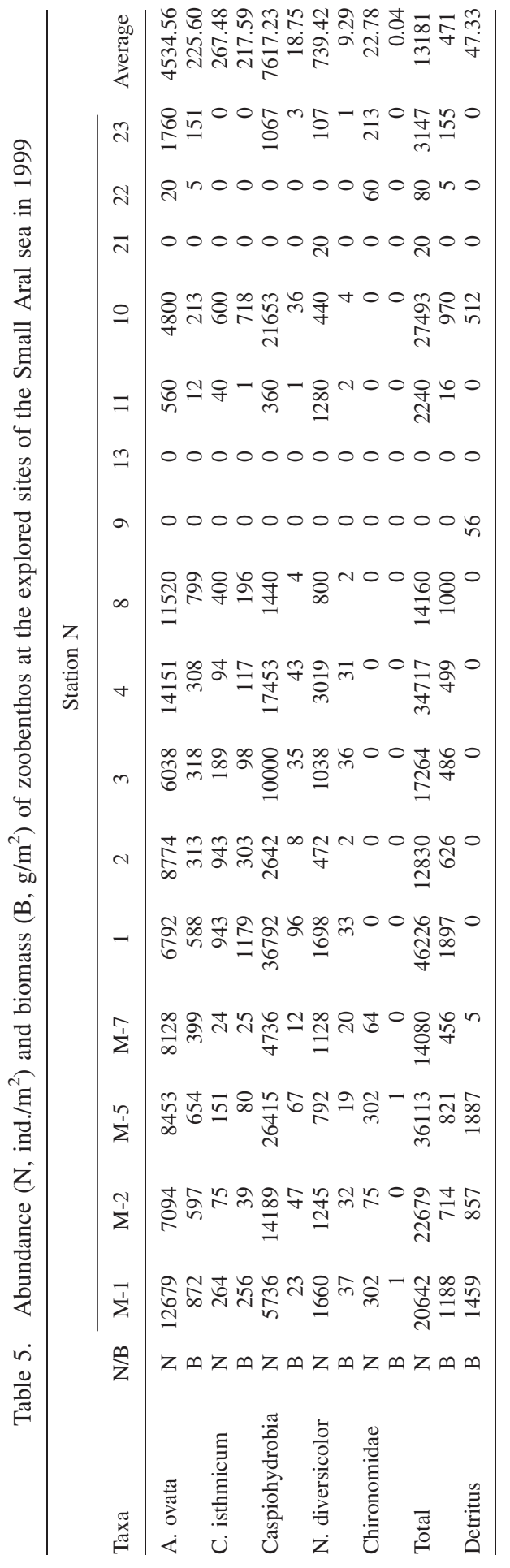


increasing depth. The vertical distribution of $C$. isthmicum had the opposite character. Polychaete abundance did not change much with depth.

Comparison of data obtained with those of previous observations in the same region showed that there were no appreciable inter-annual dynamics in the Butakov bay benthic associations. Average benthos biomass and density in 1997 did not differ much from the values registered in 1990 in the same region $\left(501 \mathrm{~g} / \mathrm{m}^{2}\right.$ and 24.5 th.ind. $/ \mathrm{m}^{2}$, respectively). Zoobenthos structure and vertical distribution were essentially similar in both periods of observation, which confirms the non-random character of the structural zoobenthos traits observed. Some distinctions in benthic invertebrate abundance recorded in 1990 and 1997 were probably connected with lack of coincidence of the sampling station frameworks in the periods of observation.

In 1999, in the benthos sample from the central Aral sea area, all the benthic taxa characteristics for the modern Aral sea, bivalves Abra ovata and Cerastoderma isthmicum, gastropods Caspiohydrobia and polichaetes Nereis diversicolor were recorded. Shrimps Palaemon elegans were numerous in nectobenthos. In contrast to previous observations at the Aral sea in 1990, chironomids Chironomus halophilus larvae were recorded in benthic communities as well. The chironomids were met in relative abundance, their density being 64 ind. $/ \mathrm{m}^{2}$ on average for the whole sea and $186 \mathrm{ind} . / \mathrm{m}^{2}$ in the inshore zone near Tastubek village (Table 6). The chironomids' presence seemed to be related to both excessive outflows of the Syr Darya river and an appreciable decrease in salinity in the Small Aral sea in spring 1999.

The results obtained showed extremely high productivity of zoobenthos in the Small Aral sea inshore zone. Density and biomass values were rather high, reaching 46 ths.ind. $/ \mathrm{m}^{2}$ and $1900 \mathrm{~g} / \mathrm{m}^{2}$, which exceeded practically all the data obtained before. In the inshore zone near the Tastubek village average benthos biomass was $795 \mathrm{~g} / \mathrm{m}^{2}$, which was much higher than any average value registered in the 1960s in any investigated site of the Aral sea.

No significant changes were observed in benthos samples between 1990 and 1997, but during the dam period from 1997 to 1999, some increases occurred in benthic biomass and productivity.

The zoobenthos vertical distribution in the inshore zone near the Tastubek village differed significantly from that at the open shores of the Aral sea but resembled that in the Aral sea bays and closed areas. Maximum zoobenthos abundance was registered at the shallow water stations, while minimum biomass was met in the deepest places. As was shown earlier (Filippov, 1995), the zoobenthos vertical distribution was largely related to the food material spatial distribution, which depended upon hydrodynamics peculiarities at the spot. In bays and gulfs characterized by low wave action, the largest amount of organic matter in sediments and correspondingly maximum abundance of benthic organisms were recorded at the shallow places. A similar situation was observed at the area near the Tastubek village. The water roughness was decreased here and maximum detritus concentration was observed in a shallow. This probably led to assemblages of maximal density forming in the shallow stations. The other possible reason of increased benthos concentration in the shallow was downward migration of benthic organisms from upper horizons as a result of sea level fall, which took place after the dam destruction in the former Berg's strait in spring 1999.

Central deep-sea regions of the Small Aral in the 1990s were permanently characterized by depressed benthic assemblages or complete zoobenthos absence (Andreev, 1999). We determined exactly the upper limit of the lifeless zone distribution in the Small Aral sea. During the period of our observation the sediments with hydrogen sulphur smell and without any traces of life were registered in the central Small Aral sea basin at a depth of up to $8 \mathrm{~m}$. Taking into account that a large part of the sea (about $46 \%$ ) has a depth of more than $8 \mathrm{~m}$, it is clear that average zoobenthos abundance in the whole sea was about half that in the inshore zone. 


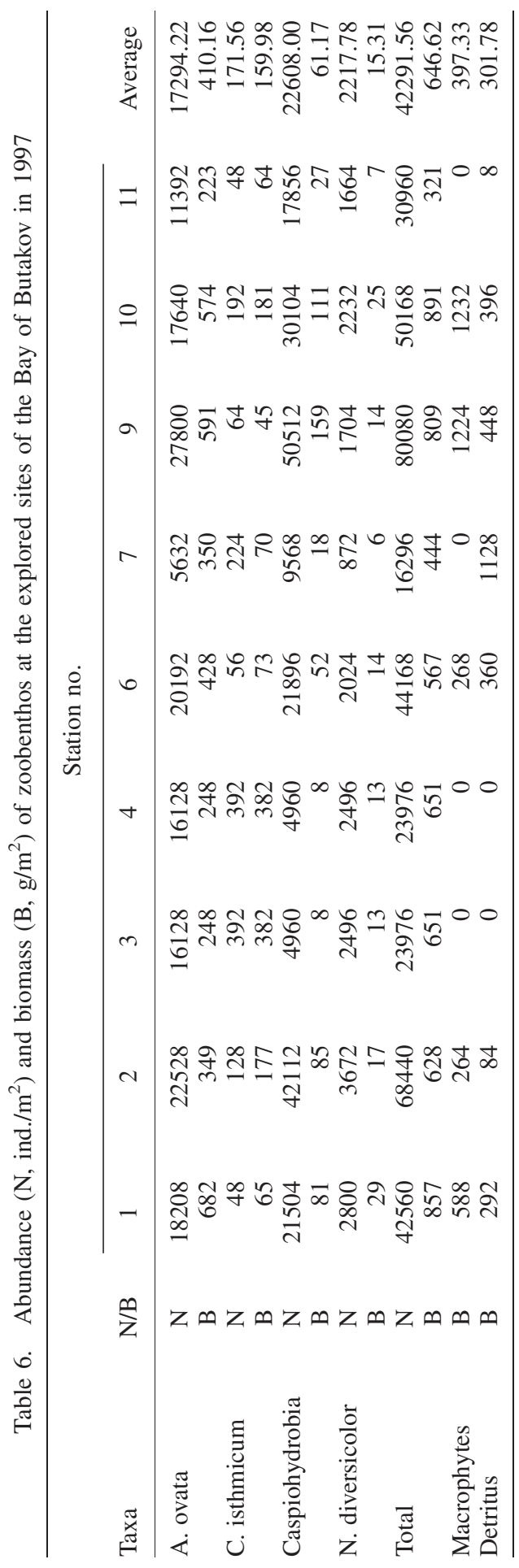


Analysis of results obtained at the sites explored some years earlier (Butakov bay, inshore zone of Tastubek peninsula, see Filippov, 1990, 1995) reveals no noticeable changes either in the zoobenthos composition or in benthic organism abundance in these areas. The relative biomass of the zoobenthos main components did not change much as well. The biomass of individual species as well as zoobenthos an the whole remained extremely high and revealed a tendency of further increase. The results obtained showed that a stable situation in the Small Aral sea benthic assemblages was retained during the 1990s. The high productivity of benthic assemblages with relative stability of the hydrological regime and the proximity of a large city make it promising for fishery restoration at the Small Aral sea.

\section{DISCUSSION}

Our theoretical studies and field researches performed in 1993-2003 revealed opportunities for reservation and rehabilitation of the northern water area of the Small Aral sea. The increase in level and decrease in salinity observed during periods of dam presence in the Berg's strait had a positive effect on rehabilitation of both Syr Darya delta and Small Aral. Construction of this dam in July 1992 and its constant strengthening has allowed the level of the Small Aral sea to rise by around $2.5 \mathrm{~m}$ and $6-7 \mathrm{~km}^{3}$ to April 1999 , and the salinity to decrease by around $8-10 \mathrm{~g} / \mathrm{l}$ down to around $20 \mathrm{~g} / \mathrm{l}$. It has been clearly assessed that periods with a dam induced a large amount of water from Syr Darya to supply the Small Aral, while periods without a dam led to less water inflow to the sea: $80 \%$ and $20 \%$ respectively. This difference is enough to explain fill in the lake with a dam. At the same time, an increase of brackish water species both in zooplankton and zoobenthos were found. In zooplankton the number of Caspian cladocerans from the Podonidae family has increased again. A few years ago representatives of the crustacean were about to disappear. In 1999, due to the decrease in salinity, their number was restored practically up to the former level. Podonevadne camptonyx were observed in large numbers and single individuals of Evadne anonyx were met again for after more than 10 years' absence. In zoobenthos, larval chironomids have appeared again. By data obtained from Aral fishery laboratory (Z. Ermakhanov, Aralsk city, personal communication) and from local fishermen, catches of flounder have almost doubled. Unfortunately, as has already been mentioned, at the end of April 1999 the dam in Berg's strait was completely destroyed by flood waters. Actually, fortunately, the quick fall of level was not accompanied by significant salinity increase. Many species that perished in Aral survived in the deltaic water bodies and, after the dam restoration, could be naturally reintroduced into the Small Aral. However, it should be stressed that this could be done only if the average salinity of the Small Aral decreased below $14 \mathrm{~g} / \mathrm{l}$.

However, in future this increase could be quite significant if the dam is not restored. Complete separation of Butakov and Shevchenko bays will be possible with the later complete drying up of both bays in 2005-2007. The destruction of the dam has already resulted in separation of Bolshoy Sarycheganak bay, which could dry up completely in one year. It is clear that the dam should be restored in the very near future. Unhampered discharge of the Small Aral sea into the Large will result in a gradual increase of its salinity, with accompanying extinction of brackish water and marine species of hydrobionts. This, in turn, will result in complete loss of the fishery importance of the Small Aral sea. The absence of a dam in Berg's strait in the distant perspective could cause complete drying up of the Small Aral and further aridization of the regional climate. This is why construction of a new solid dam, started last summer, is so crucial for the Small Aral. 


\section{REFERENCES}

Aladin NV. 1995. The conservation ecology of the Podonidae from the Caspian and Aral seas. Hydrobiologia 307: 85-97.

Aladin NV. 1999. Creeping changes in biological communities in the Aral sea. In Creeping Environmental Problems and Sustainable Development in the Aral Sea Basin. Cambridge University Press: Cambridge, UK; 261-282.

Aladin NV, Plotnikov IS, Potts WTW. 1995. The Aral sea desiccation and possible ways of rehabilitation and conservation of its north part. Int J. Environmetrics. 6: 17-29.

Aladin NV, Filippov AA, Plotnikov IS, Egorov AN, Piriulin DD, Smurov AO. 2000. Modern ecological state of the Small Aral Sea. In Ecological Research and Monitoring of the Aral Sea Deltas: A Basis for Restoration. Book 2. UNESCO Aral Sea Project. 1997-1999 Final Scientific Reports. pp. 73-81.

Andreev NI. 1991. Zooplankton of Butakov Bay (in the Aral sea) in June 1990, Proc. of Zool. Inst. Acad of Sci. USSR, vol. 237, 1991, pp. 30-33 (in Russian).

Andreev NI. 1999. Aquatic fauna of the Aral Sea under conditions of ecological crisis. Omsk, Omsk State Pedagogical University. 453 p (in Russian).

Birkett S. 1995. Contribution of TOPEX/POSEIDON to the global monitoring of climatically sensitive lakes. Journal of Geophysical Research 100(C12): 25, 179-225.

Birkett S. 1998. The contribution of TOPEX radar altimeter to the global monitoring of large rivers and wetlands. Water Resources Research 34(5): 1223-1239.

Bortnik VN. 1999. Alteration of water level and salinity of the Aral sea. In Creeping Environmental Problems and Sustainable Development in the Aral Sea Basin. Cambridge University Press: Cambridge, UK; 47-65.

Cazenave A, Bonnefond P, Dominh K. 1997. Caspian sea level from Topex/Poseidon altimetry: level now falling. Geophysical Research Letters 24: 881-884.

Dobrynin EG, Koroleva NG. 1991. Production and microbiological processes in Butakov Bay (the Aral sea), Proc. of Zool. Inst. of Acad. Off. Sci. USSR, vol. 237, pp. 49-59 (in Russian).

Filippov AA. 1991. Zoobenthos of Butakov Bay (the Aral Sea) in September 1990. Proc. of Zool. Inst. of Acad. Off. Sci. USSR, vol. 237, 1991, pp. 44-48 (in Russian).

Filippov AA. 1995. Macrobenthos of inshore zone of the Aral sea North in modern polyhaline conditions: quantity, biomass and spatial distribution. Proc. of Zool. Inst. of RAS, vol. 262, pp. 103-106 (in Russian).

Glantz MH. 1999. Sustainable development and creeping environmental problems in the Aral sea region. In Creeping Environmental Problems and Sustainable Development in the Aral Sea Basin. Cambridge University Press: Cambridge, $\mathrm{UK} ; 1-25$.

Kouraev AV, Papa F, Buarizin PI, Cazenave A, Crétaux J-F, Dozortseva J, Remy F. 2003. Ice cover variability in the Caspian and Aral seas from active and passive satellite microwave data, Polar Research 22(1): 43-50.

Letolle R, Chesterikoff A. 1999. Salinity of surface waters in the Aral sea region. International Journal of Salt Lake Research $\mathbf{8}$ : 293-306.

Micklin PP. 1988. Desiccation of the Aral sea, a water management disaster in the Soviet Union. Science 241: 1170-1176.

Mirabdullayev IM, Mustfaeva ZA, Tashmukhamedov BA. 2003. Succession of the ecosystems of the Aral sea during its transition from oligohaline to polyhaline waterbody, 35th International Workshop on Ocean Dynamics—Dying and Dead Seas, Liege, Belgium.

Orlova MI. 1995. Materials for general valuation of productional-destructional processes in the coastal zone of the northern part of the Aral sea. About some properties of functioning of the ecosystem in the district of Syrdarya's delta and in shallow areas on the gulf. Proc. of Zool. Inst. of RAS, vol. 262, pp. 48-64 (in Russian).

Orlova MI, Rusakova OM. 1995. Structural and functional characteristics of phytoplanktonic community in the district of Tastubek coge in September 1990, Proc. of Zool. Inst. of RAS. vol. 262, pp. 208-230 (in Russian).

Plotnikov IS. 1991. Zooplankton of Butakov Bay (the Aral Sea) in September 1990. Proc. of Zool. Inst. of Acad. Off. Sci. USSR, vol. 237, pp. 34-39 (in Russian).

Plotnikov IS. 1993. The Aral sea zooplankton in 1992. Proc. of Zool. Inst. of RAS, vol. 250, pp. 46-51 (in Russian).

Plotnikov IS. 1995a. The Aral sea (the Small sea) zooplankton under conditions of the regime stabilization. Proc. of Zool. Inst. of RAS, vol. 262, pp. 167-173 (in Russian).

Plotnikov IS. 1995b. Zooplankton of coastal zone of the northern part of the Aral sea under modern polyhaline conditions. Autoref. of doctoral thesis, St. Petersburg, 24p (in Russian).

Small EE, Sloan LC, Hostetler S, Giorgi F. 1999. Simulating the water balance of the Aral sea with a coupled regional climatelake model. Journal of Geophysical Research 104(D6): 6583-6602.

Small EE, Giorgi F, Sloan LC, Hostetler S. 2001. The effects of desiccation and climate change on the hydrology of the Aral Sea. Journal of Climate 14: 300-322.

Zholdasova I. 1999. Fish population as an ecosystem component and economic objet in the Aral sea basin. In Creeping Environmental Problems and Sustainable Development in the Aral Sea Basin. Cambridge University Press: Cambridge, UK; 204-224. 